\title{
INTELEGENT STICK FOR BLIND (INSTISBLIND) INOVASI ALAT BANTU MOBILITAS PENCEGAHAN KEBISINGAN HUJAN UNTUK MENINGKATKAN KEMANDIRIAN PENYANDANG TUNANETRA
}

\author{
Nur Milati ${ }^{1}$, Wahyuni Amilya ${ }^{2}$, Raden Budi Santoso ${ }^{3}$, Rendy Roos Handoyo ${ }^{4}$ \\ 1,3 Jurusan Pendidikan Teknik Elektro FT UNY, ${ }^{3,4}$ Jurusan Pendidikan Luar Biasa FIP UNY \\ email : nurmilati.2017@student.uny.ac.id
}

\begin{abstract}
The importance of using stick skills for blind people for place transfer activities. In addition, visuals are needed that require training to develop other senses, especially the sense of hearing. Sound can provide information about the location, cause, or source of an object (Strickling, 2010: 1). However, from several innovations needed for its use by blind people who have not been looked at by many innovators, namely in the form of blind sticks that can still be used when it rains. Innovators create innovations Intel Stick For Blind (Instisblind) Innovation Tools for Rain Leak Prevention Mobility to Increase the Independence of People with Blindness. Innovation uses the Linear Sequential Model (NGO) method which consists of four stages, namely analysis and study of literature, system design / design, electronic system planning (assembly-system electrnics), and testing. The objectives of this innovation are to design, work systems, and the advantages and benefits of Instisblind for the blind. The functional testing phase of the Researcher's work method in each component. Proximity sensor challenges object challenges distance of $-30 \mathrm{~cm}$. The researcher conducted a validation for media experts, obtaining $81.2 \%$ results with a decent category. Then the trial carried out by SLB A Yaketunis got a response from either the user or the blind. In this trial for users, data was collected on the usefulness of the tool and got $87.9 \%$ results with a very useful and feasible category
\end{abstract}

Keywords: rain sound dampening, blind, stick

\begin{abstract}
ABSTRAK
Pentingnya keterampilan penggunaan tongkat bagi tunanetra untuk aktivitas berpindah tempat. Selain itu hilangnya fungsi visual menuntut adanya latihan untuk mengembangkan indra-indra lain, terutama indra pendengaran. Suara dapat memberikan informasi tentang lokasi, penyebab, atau sumber suatu objek(strickling, 2010:1). Namun dari berbagai inovasi tersebut terdapat satu kondisi yang sangat dibutuhkan kegunaannya oleh tunanetra yang belum dilirik oleh banyak inovator yaitu berupa tongkat tunanetra yang tetap bisa digunakan ketika hujan. Inovator membuat inovasi Intelegent Stick For Blind (Instisblind) Inovasi Alat Bantu Mobilitas Pencegahan Kebisingan Hujan Untuk Meningkatkan Kemandirian Penyandang Tunanetra. Inovasi menggunakan metode Linear Sequential Model (LSM) yang terdiri dari 4 tahapan yaitu tahap analisis dan studi literatur, desain/perancangan sistem, perakitan sistem elektronik (assembly-electrnics systems), dan pengujian. Tujuan dari inovasi ini adalah untuk mengetahui rancangan, sistem kerja, dan keunggulan serta manfaat Instisblind bagi tunanetra. Tahap uji coba fungsional peneliti menguji cara kerja disetiap komponen. Sensor proximity mendeteksi objek rintangan jarak $+-30 \mathrm{~cm}$. Peneliti melakukan validasi kepada ahli media, memperoleh hasil $81.2 \%$ dengan kategori layak. Kemudian uji coba dilakukan SLB A Yaketunis memperoleh respon baik dari pengguna atau tunanetra. Pada uji coba kepada pengguna ini dilakukan pengambilan data terhadap kebermanfaatan alat dan mendapat hasil $87.9 \%$ dengan kategori sangat bermanfaat dan layak digunakan.
\end{abstract}

Kata Kunci : peredam suara hujan, tunanetra, tongkat.

\section{PENDAHULUAN}

Anak tunanetra adalah seseorang yang memiliki ketajaman visual 20/200 dan sudut pandang kurang dari 20 derajat (Daniel P. Hallahan, dkk. 2009: 80). Indra penglihatan merupakan salah satu alat yang mempunyai 
peran penting dalam kehidupan sehari-hari karena pemerolehan informasi atau konsep diperoleh dengan cara melihat sebesar 85\% (Suharmini, 2009: 30). Pembentukan konsep sulit berkembang pada anak tunanetra sejak lahir. Anak dengan hambatan penglihatan (tunanetra) sejak lahir seringkali mengalami kekurangan konsep dasar dan gagal untuk memaknai komponen penting suatu informasi dari lingkungan sekitarnya. Kebutuhan kompensatoris yang dibutuhkan berupa huruf Braille dan Orientasi Mobilitas (OM) agar kekurangan yang disebabkan hilangnya fungsi pengelihatan dapat dialihkan dengan mengoptimalkan fungsi tubuh yang lain.

OM digunakan tunanetra untuk mengenali lingkungan dan arah saat akan melakukan kegiatan sehari-hari. Orientasi mobilitas adalah kemampuan mengoptimalkan indra yang masih berfungsi untuk berpindah dari posisi semula ke posisi yang dikehendaki dengan selamat (Yosfan Azwadi : 2004). Adapun alat bantu orientasi mobilitas saat ini berupa : anjing penuntun (guide dog), orang awas, dan tongkat (Departemen Pendidikan Nasional,2009). Di Indonesia tongkat menjadi pilihan pertama alat bantu OM, adapun fungsi tongkat menurut Murakami dalam Mona (2012)

: 1) dapat mengurangi bantuan orang awas, 2) alat bantu dalam mengatasi rintangan secara langsung seperti mendeteksi tangga dan menentukan salah satu lokasi, 3) sebagai pelindung bagi tunanetra. Keterampilan penggunaan tongkat yang baik membuat tunanetra mampu berpindah tempat secara mandiri, lues, dan lebih mudah memahami lingkungan baru (Mona,2012).

Faktanya, terdapat hambatan kemandirian tunanetra bermobilitas terutama ditempat baru. Pertama, keterampilan penggunaan tongkat rendah membuat tunanetra sangat bergantung pada pendamping awas. Kedua, kondisi alam seperti hujan membuat tunanetra tidak dapat bergerak kecuali dibantu oleh pendamping awas meskipun sudah mampu menggunakan tongkat. Data didukung oleh hasil wawancara terhadap seorang tunanetra berinisial IM mengatakan bahwa ketika turun hujan IM tidak bisa berangkat ke tempat tujuan yang dituju secara mandiri. Menurut IM penggunaan tongkat sangat bergantung pada indra pendengaran dan penciuman sehingga ketika hujan IM mengalami kebingungan dalam menentukan arah sehingga tidak bisa berbuat apa-apa selain meminta bantuan orang lain. (Intan Mutiara Mir'attasnisa. 2017). Selain memiliki kendala saat hujan, tongkat memiliki kelemahan lain yaitu hanya mampu mendeteksi halangan dengan jangkauan terbatas sehingga tunanetra diharapkan selalu waspada dan berhati-hati saat berjalan sendirian.

Perlunya perancangan sebuah tongkat yang mampu meredam suara hujan. Alat ini dikembangkan dengan Arduino mega dan menggunakan sensor proximity karena performa yang stabil dan akurasi yang tinggi. Alat ini dilengkapi earphone/headset wereless sebagai output dari audio yang dikeluarkan sistem. Selain itu dilengkapi GPS guna memudahkan penyandang dalam mengetahui lokasi dia berada serta saklar untuk menghidupkan atau mematikan sistem. Adanya permasalahan dan potensi tersebut, peneliti menginovasikan alat bantu yaitu Intelegent Stick For Blind (Instisblind) Inovasi Alat Bantu Mobilitas Pencegahan Kebisingan Hujan untuk Meningkatkan Kemandirian Penyandang Tunanetra.

\section{METODE}

Penelitian ini dilakukan dengan berbagai tahapan mengikuti model Linear Sequential Model (LSM) yang terdiri dari 4 tahapan yang berulang yaitu tahap analisis dan studi literatur, desain/perancangan sistem, perakitan sistem elektronik (assembly-electrnics systems), dan pengujian. Kegiatan yang dilakukan untuk setiap tahap dapat dijelaskan sebagai berikut:

\section{Tahap Analisis dan Studi Literatur}

Dalam tahapan ini, peneliti telah melaksanakan analisa dan studi literature 
yang dilakukan secara manual dengan wawancara kepada penyandang tunanetra terutama di SLB A Yaketunis yang beralamat Jl. Parangtritis 46, RT/RW 66/18, Dsn. Danunegaran, Ds./Kel Mantrijeron, Kec. Mantrijeron, Kota Yogyakarta, Prov. D.I. Yogyakarta. Dikarenakan di SLB A Yaketunis terdapat banyak penyandang tunanentra yang sudah memiliki keterampilan mobilitas dan penggunaan tongkat. Tetapi dari hasil observasi didapatkan pula fakta bahwa penyandang tunanetra masih belum atau susah untuk melakukan kegiatan (orientasi mobilitas) disaat turun hujan. Mereka memilih untuk menghentikan kegiatan atau meminta bantuan orang lain untuk membantunya atau memilih berhenti menungg hujan reda. Proses pembuatan dan perakitan alat juga memerlukan studi literatur seperti membaca buku panduan ataupun menganalisa produk-produk lain yang sudah jadi.

\section{Tahap Desain/ Perancangan Sistem}

Pada proses perancangan sistem, peneliti akan merancang bagaimana cara kerja dari Instisblind. dapat berfungsi maksimal dengan komponen yang digunakan. Pembuatan rangkaian elektronik sesuai dengan kebutuhan control dari Instisblind. peneliti membuat desain atau rancangan pengembangan Intelegent Stick For Blind untuk Meningkatkan Kemandirian Mobilitas Penyandang Tunanetra. Pada tahap ini peneliti mengembangkan yang dirancang langsung dalam bentuk program atau kodding yang akan digunakan sebagai perintah dalam mikrokontroller yang digunakan. Secara garis besar sistem hanya terdiri dari empat bagian yaitu bagian utama berupa sensor ultrasonic, mikrokontroller (arduino), tongkat, dan Earphone dan baterai sebagai penyuplai energi listrik.

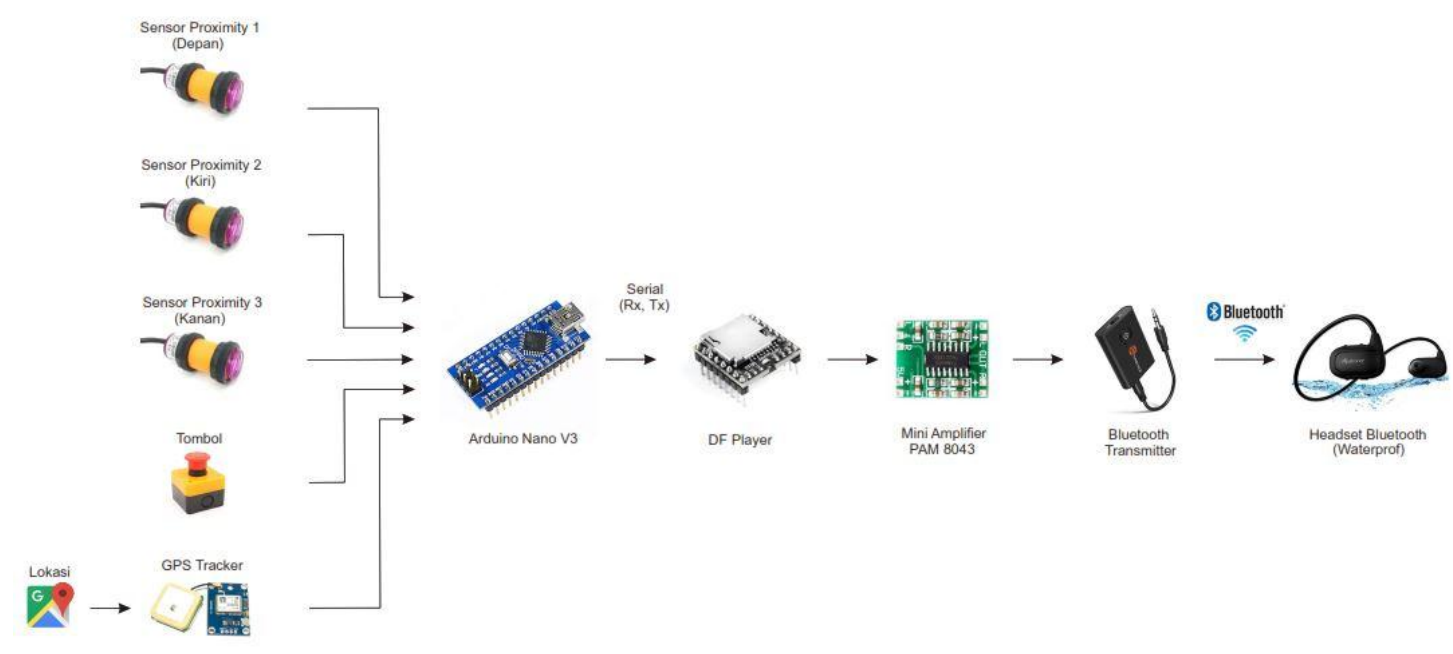

\footnotetext{
Gambar 1. Diagaram Blok

Tahap pengkodean setelah dilakukan rancangan desain kemudian diterjemahkan menjadi program guna memproses sinyal input yang masuk dari sensor jarak kedalam mikrokontroller (Arduino). sehingga hasil output berupa audio dapat memandu penyandang tunanetra untuk tetap melanjutkan aktivitasny disaat hujan turun. Langkah

pengkodean ini dilakukan menggnakan laptop maupun komputer yang telah diinstall software CVAVR.
} 


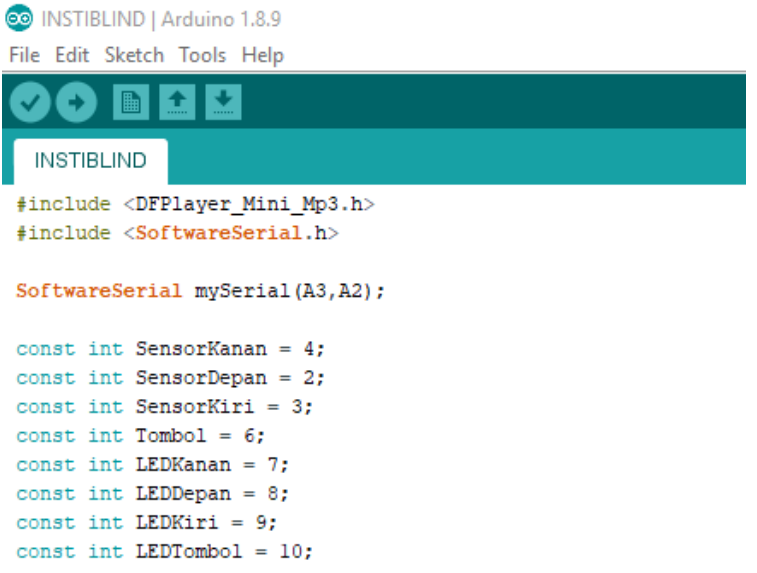

Gambar 2. Program Arduino

\section{Tahap Pembuatan dan Perakitan Sistem Elektronik}

Sistem elektronis yang digunakan pada Instisblind ini meliputi sensor ultrasonic, mikrokontroller (arduino), DFPlayer, amplifier PAM8403, bluetooth dan earphone.

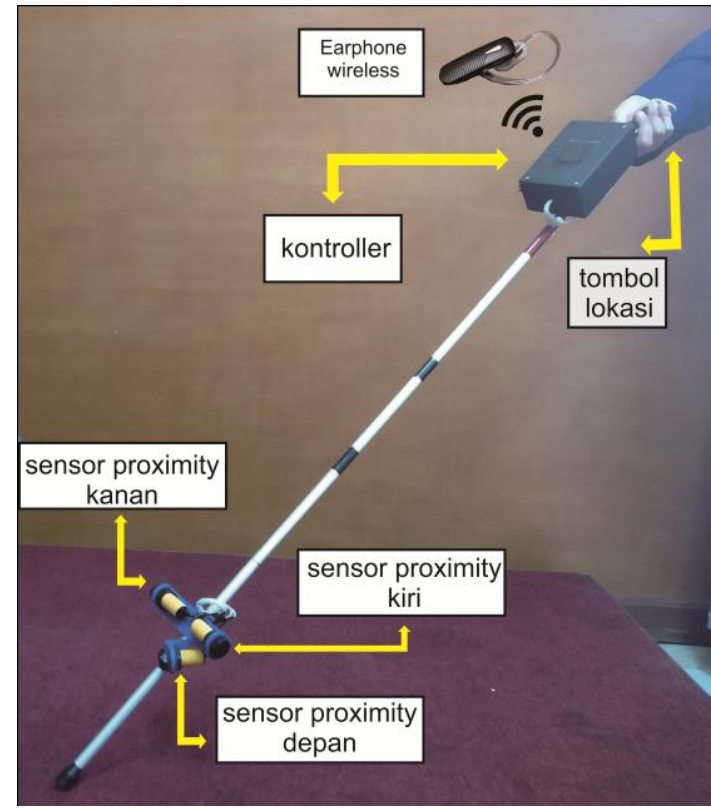

Gambar 3. Struktur Alat

\section{Tahap Pelaksanaan dan Uji Coba}

Produk awal yang telah di kembangkan diujikan kepada ahli media yaitu dosen dalam bidang media. Tujuannya untuk menemukan kesalahankesalahan yang mungkin terjadi. Setelah tahapan implementasi perakitan sistem mekanis dan elektronisnya serta dinyatakan valid oleh para ahli, selanjutnya dilakukan pengujian kinerja alat dan troubleshooting, hingga sistem berkerja sempurna seperti Instisblind (Intelegent Stick For Blind) yang direncanakan.

Setelah produk ini dinyatakan valid oleh para ahli, selanjutnya produk akan diujicobakan kepada penyandang tunanetra yaitu uji coba kepada penyandang tunanetra di SLB A Yaketunis

\section{HASIL DAN PEMBAHASAN}

Setelah melaksanakan analisis dengan melakukan wawancara kepada penyandang tunanetra di asrama SLB A Yaketunis yang beralamat Jl. Parangtritis 46, RT/RW 66/18, Dsn. Danunegaran, Ds./Kel Mantrijeron, Kec. Mantrijeron, Kota Yogyakarta, Prov. D.I. Yogyakarta pada tanggal 1 April 2019. Hasil wawancara yang dilakukan dengan saudara Taufik dan Rifki bahwa

1. Mereka memang kesulitan mobilitas ketika turun hujan, selain suara bising karena hujan mereka juga merasakan Medan yang berbeda ketika menginjakkan kaki hal ini karena ada air sehingga Medan yang sudah dikenal terasa asing karena becek air.

2. Mereka membedakan kebisingan hujan dengan kebisingan di keramaian yaitu dengan cara pendengaran mereka masih terbuka sedangkan hujan benar-benar tertutup apalagi ketika hujan memakai mantol sehingga tambah tertutup akses pendengaran kita.

3. Mereka mengatakan bahwa tidak mumungkinkan untuk memakai payung karena 1 tangan untuk megang tongkat satunya lagi untuk megang payung dirasa terlalu susah. 


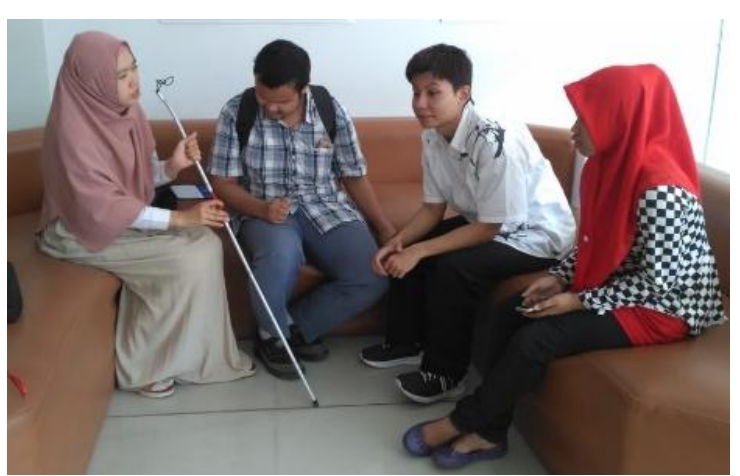

Gambar 4. Wawancara kepada Tunanetra

Selanjutnya, peneliti melakukan perancangan system dengan membuat program pada softwere Arduino dan desain menggunakan inventor. Desain ini kemudian peneliti cetak menggunakan 3D printing.

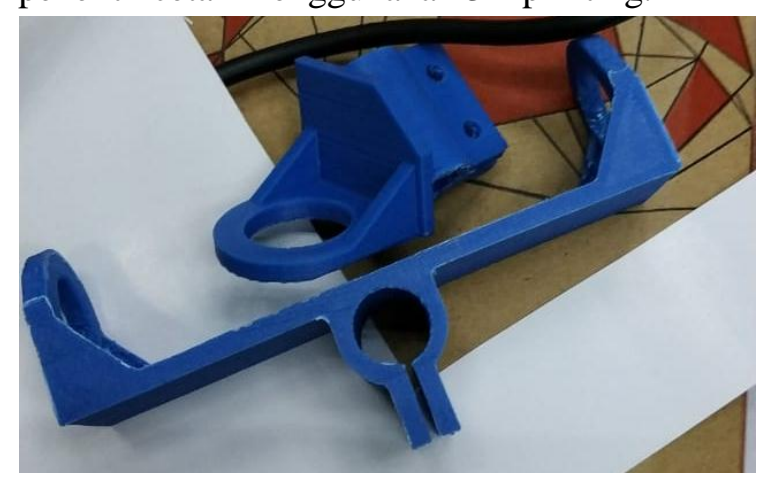

Gambar 5 Hasil Cetak 3D Printing

Pada proses desain menggunakan inventor peneliti mendesian dengan dimensi dudukan proximity kanan kiri yaitu 110 x $3 \mathrm{x}$ $30 \mathrm{~mm}$. selanjutnya peneliti merancang system kerja dari instisblind ini guna mempermudah dalam proses pembuatan codding dan perangkaian komponen elektronik. Sebelum melakukan Proses pembuatan codding, peneliti harus menginstal softwere yang akan digunakan dalam pembuatan codding yaitu softwere arduino. Di softwere ini diperlukan beberapa pengaturan dan inisal pin guna mengetahui input dan output yang akan di control oleh arduino.

$$
\text { void setup () \{ }
$$

Serial.begin(9600);

mySerial.begin(9600);

mp3_set_serial (mySerial); //set

Serial for DFPlayer-mini mp3 Module delay(1); mp3_set_volume (15);

\author{
pinMode \\ (SensorKanan, \\ INPUT_PULLUP); \\ pinMode \\ (SensorDepan, \\ INPUT_PULLUP); \\ pinMode \\ INPUT_PULLUP); \\ (SensorKiri, \\ pinMode (Tombol, INPUT_PULLUP); \\ pinMode (LEDKanan, OUTPUT); \\ pinMode (LEDDepan, OUTPUT); \\ pinMode (LEDKiri, OUTPUT); \}
}

Arti dari codding diatas untuk memberikan inisial kepada arduino bahwa sensor proximity depan, kanan, dan kiri merupakan komponen input yang kemudain akan di proses oleh arduino. Beberapa pengaturan awal yang harus pada arduino yaitu serial.begin(9600); tidak boleh terlewatkan.

else if $($ (kondisiSensorKanan $==$ LOW $)$

$\& \&$ (kondisiSensorDepan $==\mathrm{HIGH}$ )

$\& \&($ kondisiSensorKiri $==\mathrm{HIGH}))\{$

Serial.println("Sensor Kanan");

digitalWrite(LEDKanan,HIGH);

mp3_play (2); \}

else if $($ (kondisiSensorKanan $==$ LOW $)$

$\& \&$ (kondisiSensorDepan $==$ LOW)

$\& \&($ kondisiSensorKiri $==$ HIGH $)$ )

Serial.println("Sensor Kanan dan

Sensor Depan");

digitalWrite(LEDKanan, HIGH);

digitalWrite(LEDDepan, HIGH);

mp3_play (5); \}

Program diatas menjelaskan bahwa apabila sensor proximity kanan mendeteksi maka akan mengeluarkan output suara pada headset "awas, di kana nada objek". Seperti itu pula dengan program untuk sensor proximity depan dan kiri. Program ini juga di codding apabila sensor kanan dan sensor depan mendeteksi objek rintangan maka akan mengeluarkan output suara "awas, didepan dan dikiri ada objek" begitu pula apabila terdapat 2 atau 3 sensor yang mendeteksi objek rintangan maka output suara akan mengeluarkan audio sesuai dengan sensor proximity yang mendeteksi objek rintangan. 
Setelah melaksanakan pembuatan desain dan perancangan system, selanjutnya peneliti merangkai elektronik. Tahap terakhir yaitu melakukan uji coba. Pertama peneliti melakukan uji coba fungsional, validasi media, dan uji coba kepada penyandang tunanetra.

Tahap uji coba fungsional peneliti menguji cara kerja disetiap komponen agar bias di pastikan bahwa semua komponen bias bekerja sesuai system kerja yang dirancang. Sensor proximity akan mendeteksi objek rintangan dengan jarak $+-30 \mathrm{~cm}$. Selanjutnya peneliti melakukan validasi kepada ahli media dan memperoleh hasil $81.2 \%$ dengan kategori layak.

Tabel 1. Hasil Uji Fungsional

\begin{tabular}{|c|c|c|c|c|}
\hline & $\begin{array}{l}\text { Jarak } \\
\text { sensor } \\
(\mathbf{c m}) \\
\end{array}$ & $\begin{array}{l}\text { Panjang } \\
\text { tongkat } \\
\text { (cm) }\end{array}$ & $\begin{array}{l}\text { Dimensi } \\
\text { Box } \\
\text { (cm) } \\
\end{array}$ & $\begin{array}{l}\text { Jarak melakukan uji coba pengguna kepada tunanetra } \\
\text { transmitter di SLB A Yaketunis dengan subjek enam siswa } \\
\text { ke receiver } \\
\text { (cm) mang memiliki tingkat orientasi mobilitas dan } \\
\text { penggunaan tongkat yang cukup baik. Pada uji }\end{array}$ \\
\hline $\begin{array}{l}\text { Uji coba } \\
\text { fungsional }\end{array}$ & 30 & 115 & $12 \times 5 \times 8$ & $\begin{array}{l}\text { ini peneliti memberikan angket terkait } \\
\text { kebermanfaatan dari instisblind } \\
\text { mendapatkan hasil } 87.91 \% \text {. }\end{array}$ \\
\hline
\end{tabular}

Tabel 3. Rekapitulasi Angket kebermanfaatan

\begin{tabular}{|c|c|c|c|c|c|c|}
\hline No & Indikator & SS & $\mathbf{S}$ & CS & KS & STS \\
\hline 1 & $\begin{array}{l}\text { Instisblind diperlukan untuk membantu } \\
\text { mobilitas tunanetra }\end{array}$ & $66.6 \%$ & $33.3 \%$ & - & & \\
\hline 2 & $\begin{array}{l}\text { Instiblind membantu tunanetra untuk } \\
\text { tetap menggunakan tongkat ketika hujan }\end{array}$ & $66.6 \%$ & $16,6 \%$ & $16,6 \%$ & & \\
\hline 3 & $\begin{array}{l}\text { Instisblind efektif membantu tunanetra } \\
\text { dalam bermobilitas ketika hujan karena } \\
\text { dapat mencegah kebisisngan hujan }\end{array}$ & $50.0 \%$ & $33.3 \%$ & $16,6 \%$ & & \\
\hline 4 & $\begin{array}{l}\text { Instisblind membantu tunanetra untuk } \\
\text { mendeteksi objek yang ada di depan. }\end{array}$ & $50.0 \%$ & $50.0 \%$ & - & & \\
\hline 5 & $\begin{array}{l}\text { Instisblind membantu tunanetra untuk } \\
\text { mendeteksi objek yang ada di kiri. }\end{array}$ & $66.6 \%$ & $33.3 \%$ & - & & \\
\hline 6 & $\begin{array}{l}\text { Instisblind membantu tunanetra untuk } \\
\text { mendeteksi objek yang ada di kanan. }\end{array}$ & $66.6 \%$ & $33.3 \%$ & - & & \\
\hline 7 & $\begin{array}{l}\text { Instisblin membantu mendeteksi objek } \\
\text { yang ada di depan, kiri, dan kanan }\end{array}$ & $50.0 \%$ & $50.0 \%$ & - & & \\
\hline 8 & $\begin{array}{l}\text { Instisblin membantu tunanetra } \\
\text { menentukan posisi/lokasi. }\end{array}$ & - & $33.3 \%$ & $66.6 \%$ & & \\
\hline
\end{tabular}

Tabel 2. Hasil Validasi Media

\begin{tabular}{ll}
\hline Indikator & $\begin{array}{l}\text { Persentase } \\
(\mathbf{c m})\end{array}$ \\
\hline Operasional media & $96.6 \%$ \\
Tampilan Teks/ Tulisan & $93.3 \%$ \\
Kualitas Visual & $92.0 \%$ \\
\hline
\end{tabular}

Uji fungsional mendapatan hasil bahwa instisblind ini akan bekerja sesuai rancangan system apabila sensor proximity mendeteksi objek rintangan paling jauh $30 \mathrm{~cm}$ dari sensor. Kemudian akan dikontrol oleh arduino yang akan mengeluarkan suara sesuai program yang telah dibuat.

Tahap validasi media dengan bapak Eko Prianto,. M.Eng. mendapatkan hasil $81.2 \%$ dengan kategori layak, kemudia peneliti melakukan uji coba pengguna kepada tunanetra siswa an tela 
Perhitungan skor ini menggunakan rumus menurut Arikunto (2009:4) dengan rumus sebagai berikut :

Presentase kebermanfatan

$$
\begin{aligned}
& =\frac{\sum \text { Skor observasi }}{\sum \text { Skor yang diharapkan }} \times 100 \\
& =\frac{211}{240} \times 100 \%=87,9 \%
\end{aligned}
$$

Total skor kebermanfatan dari data pengguna sejumlah 211 (87,9\%) dari skor yang diharapkan yaitu 240 (100\%). Berdasarkan kriteria pada tabel kelayakan menurut Arikunto (2009: 4), total skor tersebut termasuk dalam kategori Sangat Layak

\section{SIMPULAN}

Pkm ini menghasilkan produk tongkat berbasis audio untuk mencegah kebisingan hujan yang dikembangkan menggunakan model Linear Sequential Model (LSM) melalui 4 tahapan yang berulang yaitu tahap analisis dan studi literatur, tahap desain/perancangan sistem, tahap perakitan sistem elektronik (assemblyelectrnics systems), dan pengujian. Produk ini terdiri atas beberapa komponen utama yaitu tiga sensor proximity, controller (arduino) sebagai kendali pusat, headset yang digunakan untuk mendengar audio sebagai reaksi terhadap sensor yang mendeteksi rintangan, dan tongkat tunanetra. Instisblind seagai media tongkat dengan audio yang berbunyi secara otomatis apabila sensor mengenai objek yang ada di samping kanan, atau kiri dana tau depan. Peneliti malakukan uji coba yang pertama yaitu 1) uji coba fungsional ang dilakukan oleh tim, 2) divalidasi oleh ahli media dengan hasil skor $81.2 \%$ dengan kategori layak untuk digunakan, 3) Uji coba satu dan dua di SLB A Yaketunis dan mendapat hasil $87.9 \%$ dengan kategori sangat bermanfaat bagi penydangan tunanetra.

\section{DAFTAR RUJUKAN}

Arief, Sadiman, , S. 2009. Media Pendidikan: pengertian, Pengembangan, dan Pemanfaatannya. Jakarta : PT Raja Grafindo Persada.

Azzahro, Affifah \& Kurniadi, Dedy. 2017. Penggunaan Tongkat pada Siswa Tunanetra SMALB dalam Melakukan Mobilitas. JASSI Anakku. Vol 18. No 1.

Mutiara Mir'atannisa, Intan. 2017. "Resiliensi Mahasiswa Tunanetra (Studi Kasus Terhadap Mahasiswa Tunanetra Tidak Dari Lahir Di Fakultas Ilmu Pendidikan Universitas Negeri Yogyakarta)". Fakultas Ilmi Pendidikan. Universitas Negeri Yogyakarta. Yogyakarta.

Hallahan, D. P.; Kauffman, J.F; \& Pullen P.C. (2009). Exceptional Learners-Cetakan ke-11. United State: Pearson.

Modul Training of Trainer Pendidikan Inklusif, Departemen Pendidikan Nasional 2009

Parkinson, B. W. 1996. Mengungkap Cara Kerja GPS Receiver (Global Positioning System. American Institute of Aeronautics and Astronautics, Washington, D.C.

Suhaeb S. 2016. Tongkat Elektronik bagi Tunanetra Berbasis Ultrasonik dan Mikrokontroler ATMEGA 8535. Jurnal Scientific Pinisi. Vol. 2 No. 2: 131- 135.

Tin Suharmini. (2009). Psikologi Anak Berkebutuhan Khusus. Yogyakarta: UNY Press.

Zain R. Z, Warto N, Masri M. 2016. Gambaran Perilaku Remaja Terhadap Penggunaan Earphone Pada Siswa SMA Negeri Kota Padang. Jurnal Kesehatan Andalas. Vol. 5 No. 3: 739-741. 